\title{
Diplomacy of Attalus I in Asia Minor, 241-216 BC
}

\author{
Tomasz Grabowski \\ Jagiellonian University in Kraków
}

\begin{abstract}
Attalus III based the position of his state in Asia Minor mostly on his military successes. Nevertheless, he skilfully enhanced these successes with diplomacy. His most important tools in this respect became euergetism, philhellenism, as well as making appropriate use of the popularity that was brought by his victories over the Galatians. Establishing relationships with the Greek states of Asia Minor was of considerable importance for the Attalids' state. In this respect, Attalus' achievements are indisputable.
\end{abstract}

Key words: Attalus I, the Attalids, Pergamum, the Galatians, the Seleucids, the Ptolemies.

Attalus I was the Attalid who introduced the Kingdom of Pergamum to the great politics of the Mediterranean world. As a result of his active policy in the Aegean basin, the dynasty captured bases in the Aegean Sea, marking a strong manifestation of its presence in the region as well as establishing relationships with numerous Greek states and with Rome. ${ }^{1}$ Attalus I was famous, above all, for his military actions, but he is sometimes considered to have been less successful in the field of diplomacy. This particularly applies to references to Eumenes II, during whose reign Pergamum's power reached its zenith. ${ }^{2}$ In fact, Attalus I engaged in numerous military actions. As in the case of the other Hellenistic monarchs, war was an inseparable part of the existence of the kings of Pergamum, and Attalus was no exception in this respect. War was, as a matter of fact, often an extension of diplomacy. In the complicated circumstances that Asia Minor witnessed in the third century, ${ }^{3}$ only a dexterous combination of diplomacy with military actions could result in attaining ambitious goals.

Asia Minor in the third century was an area where the influences of the most powerful dynasties - the Seleucids and the Ptolemies in particular - clashed, constituting a chance for the minor states of the region. Emancipation of various dynasts in the region led to the establishment not only of the state of the Attalids, but also of the kingdoms of

\footnotetext{
${ }^{1}$ For Attalus I's policy in the Aegean, cf. Allen 1971; 1983, 65-75; Grabowski 2016, 82-93.

2 Allen 1983, 27.

${ }^{3}$ All dates in the paper are BC.
} 
Bithynia, Pontus or Cappadocia. ${ }^{4}$ Since the 270s, first the invasions and then the Celtic settlement had become a new and important factor. Finally, the Greek cities of Asia Minor constituted another significant issue.

The poleis of western Asia Minor must have drawn particular attention from the Attalids. The region was densely populated. The Greek cities that existed there were characterised by great diversity in terms of their political position as well as demographic and economic potential. Apart from the weaker cities, which recognised the superior power of different Hellenistic kings, there also existed some strong poleis, predominantly wealthy, with a long and rich history, and sometimes possessing vast territories. Most importantly, their financial resources allowed them to keep their own armies consisting not only of their citizens, but also of mercenary divisions. Thus although the majority of the region was made up of small communities, a few of them possessed a significant political potential. The two most important cities of Ionia, Ephesus and Miletus, remained almost throughout the whole third century under the control of the Seleucids or the Ptolemies. Both amassed considerable riches and still enjoyed wide prestige. Ephesus, thanks to the steps taken by Lysimachus, which was transferring the city to a new place and increasing its population with settlers from Lebedus and Colophon, remained the biggest polis of the region. The city's chief assets were its location on the trade routes as well as the control it exerted over a rather extensive and fertile region. Miletus was the subject of Lysimachus' efforts, then the Seleucids and the Ptolemies both desired to possess it. The epigraphic evidence indicates that although a twenty-year period of Ptolemaic rule was exasperating for the citizens of Miletus, their relationships with the Seleucids developed much better. The city and the oracle in Didyma, which was under its control, were in the rulers' good graces and enjoyed high prestige. ${ }^{5}$ Smyrna was also an important centre. It quickly associated itself with the Seleucids and consistently forged bonds with this dynasty. This loyalty did not express itself only in the development of the cult of the members of the Seleucid family, but was also manifested during the Third Syrian War. At that time, Smyrna supported Seleucus II and Seleucus III, in exchange for which significant privileges were bestowed upon it. ${ }^{6}$ Cyzicus was one of the most powerful Greek cities in Asia Minor. The most important polis of Propontis possessed, in Greek terms, a vast territory, which together with the profits trade constituted the basis of the city's economy. It retained independence during the whole Hellenistic period. It was just the power of Cyzicus, as well as the presence of the other poleis, such as Ilium, Lampsacus or Abydos, that effectively prevented the Attalids' northbound expansion in the sea region. Another influential and important centre in the region was Byzantium, the city that gained its wealth predominantly due to trade, but also through controlling a substantial territory in the Thracian region. ${ }^{7}$ It was the presence of these and other independent poleis in Asia Minor that made the political actions in the region particularly complicated.

4 See Heinen 1984, 425-426.

5 OGIS 213 = I.Didyma, no. 48; OGIS 214 = Welles 1934, no. 5; OGIS $227=$ Welles 1934, no. 22; I.Milet, no. 1, cf. also App. Syr. 65; Paus. 1.16.3; Bringmann - von Steuben 1995, 334-346, nos. $280-282$.

${ }^{6}$ OGIS 222; 228; 229; I.Smyrna, no. 573; Robert 1937, 90; see also Ma 2002, 49-50; Capdetrey 2007, 207-208.

${ }^{7}$ In truth, the city had to a pay a tribute to the Celtic state of Tylis, but its size (80 talents: Plb. 4.46) also proves the scale of wealth the Byzantines accumulated. 
The poleis of Asia Minor also possessed a long tradition of diplomatic activity. In the Hellenistic world, dominated by large monarchies, poleis seemingly found themselves in a difficult situation as far as conducting a foreign policy is concerned. This was how it was in the case of great politics. The Greek cities, however, found some new platforms for their activity. Attempts at arbitration were eagerly taken up, the treaties of proxenia, asylia and isopoliteia were made, ${ }^{8}$ and cooperation in the fields of religion and economy was developed. Some regional forms of cooperation were also continued. Consisting of numerous Ionian poleis, the Ionian League played the role of such a connector in the religious field. In the period of the Diadochi, the Troad League was set up. ${ }^{9}$ Organised around the temple of Athena Ilias in Ilium, it was also an organisation of a predominantly religious character.

The rivalry of the powers was also in the cities' favour. It was already during the Diadochi's fights that the issue of the Greek cities' independence became a new, important propaganda slogan, which was used for the first time by Polyperchon. ${ }^{10}$ Taken up and practically applied to a much larger extent by Antigonus I Monophthalmus, and then Ptolemy, ${ }^{11}$ it became a significant tool of political fight and the kings' diplomacy as regards the poleis. The problem of the poleis' independence from the very beginning was treated instrumentally, but the propaganda slogan in question also opened some new opportunities for the Greek cities. ${ }^{12}$ Each Hellenistic ruler had to have this issue in mind. Friendly relationships with the Greek cities made the free draft of mercenaries possible and considerably facilitated implementing the policy in a particular region. The Greeks' support was the basis for the existence of the Hellenistic monarchies. Therefore, developed royal euergetism could be observed. The above factors must have been taken into account by the Attalids when they built their position in the world: particularly in the light of the very well developed urban life in Asia Minor. Politics in the region demanded dexterity as well as appropriate dosing of flattery and pressure. Traditional bonds and the complicated network of local conflicts between the Hellenistic powers should also have been taken into consideration.

The policy of Attalus I's predecessors was characterised by great caution. Both Philetaerus and Eumenes I slowly but adeptly built the dynasty's position in the region. Their prudence, but also their ability to gradually attain goals, can be seen in particular, for example, through their policy towards the Seleucids. Although Philetaerus achieved a considerable degree of independence, he officially emphasised his dependence in the relationship with Antiochus I, the best example of which is the iconography of the coins that he minted. ${ }^{13}$ A similar policy was led by his successor, Eumenes I. Even after his victory over Antiochus II in the battle near Ephesus, circa 261, he did not assume the

${ }^{8}$ Some of the leaders of this kind of activity in the Greek world were Cyzicus and Miletus: McShane 1964, 51-52.

${ }^{9}$ The League is proved to have existed in $306\left(\operatorname{SIG}^{3} 330=\right.$ I.Ilium, no. 1$)$.

${ }^{10}$ Diod. 18.56.

${ }^{11}$ Diod. 19.61.3; 62.1.

${ }_{12}$ As regards the role that the issue of the poleis' independence played in the diadochs' and their successors' politics, see Heuss 1937, 216-244; Koehn 2007, 48-50; Dmitriev 2011, 114-142.

${ }_{13}$ The obverse showed an image of Seleucus I, and the reverse Athena, the protector of Pergamum: Newell 1936, 1-34; Westermark 1961, 20-21. 
royal title. However, the coins with a portrait of Philetaerus - not Seleucus, as had been the case before - probably minted after this victorious battle, prove the fact that Eumenes stressed his independence from the Seleucids. ${ }^{14}$

The actions of the first two representatives of the dynasty in their dealings with the western and northern Greek communities of Asia Minor were characterised by similar cautiousness. Their policy led to reinforcing the dynasty's control over the valley of the River Caïcus. They both delineate the main lines of Pergamenian diplomacy - euergetism and philhellenism. Based on those tools, Philetaerus dexterously tightened the relationships with the neighbouring cities. By using substantial financial resources,${ }^{15}$ he developed the strategy of diplomatic investments. He generously supported the cities of Asia Minor, e.g. Cyzicus, Cyme and Pitane in Aeolis, Mysian Aigai, as well as Beotian Tespiai and Oropus, situated in inland Greece. ${ }^{16} \mathrm{He}$ also skilfully used the threat of the Galatian invasion to create his image as the Philhellene who showed care towards Greek cities. ${ }^{17}$ Eumenes I continued this policy. A particular place in the diplomacy of the rulers of Pergamum was held by Greek sanctuaries, their undeniable success having been underlined by assuming the status of Delphi's proxenoi. ${ }^{18}$ At the same time, the first Attalids strove not to emphasise their position as the rulers of Pergamum while making donations. ${ }^{19}$ The idea behind this was to create an image of the rulers of Pergamum that was less monarchic, but closer to the tradition of a polis, in comparison with the other Hellenistic kings. A similar goal was to be achieved by maintaining in the capital traditional institutions of a Greek polis, as well as the Attalids' residence, which was devoid of regal sumptuousness. ${ }^{20}$

Philetaerus and his followers therefore succeeded in building friendly relationships with the numerous neighbouring Greek cities in the region as well as creating an image of the Attalids as defenders and protectors of Greek culture and the Hellenes in northwest Asia Minor. When establishing his rule in 241, Attalus I had already had a very good point of departure, which was the basis of his power and the relationships with the communities of Asia Minor created by his predecessors. Eumenes I's capture of Elaea was

14 The inscription concerning Eumenes I's agreement with the revolting mercenaries from Philetaireia and Attaleia has a similar tone. For this topic, see Westermark 1961, 12-13; Allen 1983, 23-25; Kosmetatou 2001, 111-114; Evans 2012: 15-18.

15 Philetaerus took over the treasure of 9000 talents, which had been deposited in Pergamum and entrusted to him by Lysimachus: Strab. 13.4.1.

16 OGIS 310-312; 335; 748-749, I.Orop., no. 388; cf. Bringmann - von Steuben 1995, nos. 86-89, 251, 252, 256-257. In the case of Oropus, the benefactor was Eumenes, Philetaerus' brother. For this aspect of Philetaerus' politics, cf. Schalles 1985, 33-41. For the contacts with Cyme, cf. Manganaro 2000; Gauthier 2003; Buraselis 2012, 252-253. For Cyzicus, cf. Atkinson 1968, 44-45; Hansen 1971, 19; Allen 1983, 14-15, 137.

17 Donations for Cyzicus were a back-up in the case of the threatening conflict with the Galatians.

18 Holleaux 1938, 9-16. Further manifestations of the importance that religious propaganda played in Philetaerus' diplomacy were the funding of Apollon's temple in Aigai (OGIS 312), or the refunding of the Magna Mater (Mother Goddess) sanctuary on the hill, south of Pergamum, see McShane 1964, 42; Allen 1983, 15-16.

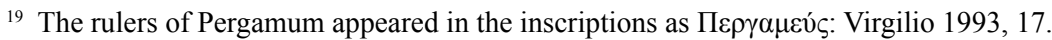

${ }^{20}$ Koehn 2007, 61. It cannot be ruled out that the Attalids used in this aspect some prestige which had been enjoyed by the city of Pergamum before. As a matter of fact, little is known about the history of the city before the Attalids, but the temple of the Mother Goddess, which was situated in the city's close proximity, might have been of some importance: Allen 1983, 15-16. 
the key factor in terms of greater political ambitions. The city became the Attalids' main port. ${ }^{21}$ Elaea became the dynasty's window on the Aegean Sea, which must have given the rulers of Pergamum a new political impulse. ${ }^{22}$ Attalus was able to actively join the Aegean policy. His major focus, however, was still Asia Minor, as it was there that the most vital interests of his state were to be found. Against the permanent rivalry between the Ptolemies and the Seleucids, which also concerned Asia Minor, and in the face of the still unsolved problem of the Celtic threat, Pergamum had a chance to become an attractive alternative for the Greek cities of the region.

The long period of Atallus I's rule, particularly his activity in Asia Minor, is relatively poorly documented in terms of sources. Moreover, the documentation that we possess focuses above all on military aspects. The literary accounts are scarce. As a matter of fact, only the passage by Polybius (5.77-78) dedicated to the king's expedition of 218 provides us with a little more information. Epigraphic sources contain merely fragmentary pieces of information, on the basis of which it is rather difficult to create a cohesive image of his politics; specifically, considering the fact that for Asia Minor it was a particularly turbulent time and the political situation changed extremely dynamically. This was the time of the Third Syrian War between the Ptolemies and the Seleucids and the "War of Brothers" among the Seleucids themselves, which brought about immense weakening of the dynasty, so far the most important factor guaranteeing stability in Asia Minor. The battles between Seleucus II and Antiochus Hierax, in which the other states of Asia Minor were also involved, deepened the chaos. Actually, the end of the civil war was not synonymous with a state of stability in the Seleucids' kingdom. Similarly to Antiochus Hierax before, the following representative of the Seleucid rule in Asia Minor, Achaeus strove to create an independent state in the region. Initially, he remained loyal towards the new king, Antiochus III, but in 220 he assumed the royal title. ${ }^{23}$ Eventually, Attalus and the Greek cities had to face up to the still unsolved Galatian problem. It seems that this was just the last factor that constituted, by and large, the key to his diplomacy. Attalus achieved a series of victories in the fights with the Galatians, both on his own and by

${ }^{21}$ It kept this position until 188, when the Treaty of Apamea gave the Attalids Ephesus, which took over the role of the most important port of the Kingdom of Pergamum. For Elaea, see Pirson 2004; 2014.

${ }^{22}$ It is very likely that Eumenes I embarked on the programme of building the Pergamum fleet; however, the first source information concerning its activity refers to the period of Attalus' rule, specifically to the First Macedonian War. The silence of the sources need not be surprising. Each state's fleet entered the scope of the ancient authors' interest the moment it started its military actions, particularly in the conflicts, the character of which was not merely continental. Ordinary, everyday actions did not evoke any emotions. In the first period, the fleet was probably the means, the purpose of which was to improve communication and connections with the maritime cities of Asia Minor, particularly with the poleis of continental Greece.

${ }^{23}$ Polybius (4.48.11) attributes this decision to Achaeus' exaggerated ambition; he had supposedly become audacious following his successes in the war against Pergamum. Researchers have tried to explain the decision in various ways. It has been suggested that perhaps Achaeus borrowed the idea from Antiochus Hierax, who had had the royal title and had also resided in Sardis. It has also been pointed out that - as is indicated, for example, by the coins minted in Sardis even before the usurpation, which bore dynastic symbols - Achaeus might have truly believed in his right to the throne. The hypothesis that his fear of Hermeias' intrigues or other unfriendly people surrounding Antiochus drove Achaeus to do such a thing is another guess. Further, it cannot be excluded that Achaeus received false news of the king's death in the eastern provinces. Finally, Achaeus might have been influenced by Ptolemaic diplomacy. Cf. Schmitt 1964, 171-173; Huss 1977, 35-36; Will 1979-1982, II: 23-26; Ma 2002, 57; Grabowski 2011, 117; Chrubasik 2016, 84, $102-112$. 
means of his mercenaries in the service of Antiochus Hierax. ${ }^{24}$ The successes in the conflict with the Galatians played a considerable role in strengthening the Attalids' power and consolidating their state. On the rising tide of his attainments, Attalus I assumed the royal title. From that moment on he could introduce himself as the one who, in accord with the Hellenistic royal ideology, ruled over chora dorikteos. Victorious campaigns against the Galatians brought Attalus fame and genuine popularity among the citizens of the Greek cities. Propaganda popularised the image of Attalus as the one who had saved the Greeks from the barbarians, and this motif became one of the most important tools that the king used in diplomacy. The successes were incarnated in the form of the monument that was erected in Pergamum. ${ }^{25}$ The references to the fights with the Galatians can be found in the inscriptions from Asia Minor. ${ }^{26}$ But, they were also used by Attalus in the politics beyond this region. The monuments erected in Delos and Athens ${ }^{27}$ propagated the image of Attalus as the defender of the Hellenistic civilisation, as a result of which he facilitated the process of initiating and tightening the relationships with the Greek inland states as well as in the island world. ${ }^{28}$ The memories of the Celtic invasions of Greece at the beginning of the 270 s were still alive, but certainly such a propaganda motif must have worked effectively in Asia Minor. It is much more difficult to reconstruct the actions of Pergamum's diplomacy during the fights with the Galatians as regards the Greek cities. Attalus refused to pay tribute to the Galatians, ${ }^{29}$ but we still do not know whether he managed to convince the other Greek poleis to do so.

The Greek cities in Asia Minor must have been the object of Attalus' efforts - particularly in the situation in which the king of Pergamum found himself at the time. Obviously, the Seleucids' problems constituted a great chance for Attalus to extend his influence. Nevertheless, the following Seleucid kings (Seleucus II, Seleucus III, and also, for some time, Antiochus III) as well as the strategoi representing their interests (Antiochus Hierax and Achaeus) were dangerous opponents. In the civil war between Seleucus II and Antiochus Hierax, Attalus initially assumed a wait-and-see attitude. After the defeat

24 Texts of the inscriptions placed on the monument to commemorate the victory list the Galatians before Antiochus Hierax. According to Launey (1949-1950, 305-306), this indicates that the Galatians were Hierax's allies, not ordinary mercenaries. However, this argument is not convincing, as exposing the fights with the Galatians was the principal motif in Attalus' propaganda. In this way he gained the position of the most important defender of the Greeks and the Hellenistic culture. The chronology of Attalus' actions is difficult to establish; see Allen 1983, 28-35; Strobel 1996, 257-262; Ma 2002, 45-47.

25 OGIS 273-279; cf. Schalles 1985, 51-104; Mitchell 2003, 284-285.

${ }^{26}$ Cf. list of monuments and inscriptions in Allen 1983, 195-199.

27 IG XI 4.1109-1110; Paus. 1.25.2; Bringmann - von Steuben 1995, 221-223, nos. 173-174. Cf. Schalles 1985, 60-64. The details of the context in which Epigenes' statue was built are unknown, but it is valid to think of it as a form of commemorating Attalus' victory against the Galatians.

28 The Galatian elements of Attalus' propaganda and diplomacy might have, by and large, facilitated establishing the relationships with the Aetolian League. What the Attalids and the Aetolians had in common were similar propaganda accents which they applied in building their image in the Greek world. Both of them emphasised their role in defending the Greek world against the barbarian Celts. Cf. Nachtergael 1975, 209-391; Schalles 1985, 51-127; Hannestad 1994; Strobel 1994; Marszal 2000, 191-212; Kosmetatou 2003, 170-171; Mitchell 2003, 284-287.

${ }^{29} \mathrm{He}$ is supposed to have done so as the first ruler of Asia Minor: Liv. 38.16.14. It cannot be ruled out that the victory in the battle with the Galatians was also ensured by Philetaerus. In spite of this, he still paid tribute to the Galatians, cf. Allen 1983, 31, note 8, 136-137. 
which Seleucus II suffered in the battle of Ancyra (circa 240/239), he had to accept Hierax's power in Asia Minor. In this way, Antiochus Hierax became a natural enemy of Attalus and, as we know, the ruler of Pergamum defeated him in a few battles. We do not have information concerning any attempts made by Attalus to win over the other kingdoms of Asia Minor. They are, however, very unlikely, as their interests did not coincide with those of Pergamum. Moreover, the rulers of those states were mostly associated with the Seleucids. The kings of Cappadocia (Ariarathes III) and Pontus (Mithridates II) were married to the daughters of Antiochus II, and Antiochus Hierax took as his wife the daughter of Ziaelas, the king of Bithynia. ${ }^{30}$ The marriages became entrenched in the Seleucids' political strategy, which pragmatically assumed the independence of the states, the conquest of which was impossible. The dynastic relationships allowed close relationships to be maintained with them. Obviously, in the face of the complicated relationships in the Seleucid family as well as the civil war, the rulers of Cappadocia, Bithynia and Pontus had to decide which side of the conflict they were on. Probably both Mithridates and Ariarathes supported Antiochus Hierax. ${ }^{31}$ We do not know if the king of Bithynia was also involved in the "War of Brothers," but taking into consideration the fact that Hierax was his son-in-law, Ziaelas too would have surely taken his side. Spice was added to the affair by the fact that Ziaelas was also closely associated with Ptolemy III. ${ }^{32}$ The development of the situation in Asia Minor must have been observed with interest in Alexandria, especially in the face of the threat potentially hanging over the Ptolemaic provinces newly regained or conquered in the recently finished Third Syrian War. Considering the principles of the Ptolemaic politics, Ptolemy III's sympathies were probably on Hierax's side. It was his actions, in fact, that meant weakening the Seleucids' power in this region. As far as we know, Ptolemy did not intervene in the "War of Brothers," although he supported Hierax when he contended with the mutiny of his Galatian mercenaries in Magnesia. ${ }^{33}$ Therefore, considering the fact that Antiochus Hierax was one of the most important opponents of Attalus I, these three kingdoms (Bithynia, Cappadocia and Pontus) were beyond the scope of Pergamum's diplomacy interests.

In this situation, the importance of poleis increased for Attalus, who must have actively sought their support. In addition to euergetism, ${ }^{34}$ the image of the defender against the barbaric Galatians was surely the most important trump card in the hands of the king of Pergamum. It was around this time, filled with fighting, that the title Soter ("saviour") began to accompany Attalus' name. ${ }^{35}$ Political marriages were a traditional diplomatic tool, frequently used by the Hellenistic kings. They were treated as an extremely convenient form of bilateral friendly relationships. A personal relationship was created through dynastic bonds. All the more interesting is the case of Attalus I, who did not choose his

${ }^{30}$ Diod. 31.19.6; Just. 38.5; Porph. FGrH 260, F32, 6, 8; cf. Seibert 1967, 56-59.

${ }^{31}$ Porph. FGrH 260, F32, 8; see Heinen 1984, 429.

${ }^{32}$ In the letter to the citizens of $\operatorname{Kos}\left(S I G^{3} 456, l l .22-26=\right.$ Welles 1934, no. 25, ll. 22-26) the king of Bithynia emphasised his close relationships with Ptolemy III, whom he addressed as philos kai symmachos.

${ }_{33}$ Porph. FGrH 260, F32, 8; Beyer-Rotthoff 1993, 74-76; Hölbl 2001, 54; Huss 2001, 363, contra Will 1979-1982, I: 299.

${ }^{34}$ Cf. Attalus I's donations, collected in Bringmann - von Steuben 1995, nos. 26, 76, 91, 92, 103, 172 175, 226, 228, 231, 253, 272 (certain) and nos. 27, 262, 374, 394, 415 (uncertain but likely).

${ }^{35}$ Virgilio 1993, 38-39; Muccioli 2013, 168. 
wife from one of the royal families, but married Apollonis, the daughter of a citizen of Cyzicus. ${ }^{36}$ In this way, the king of Pergamum strove for three goals. First, he emphasised his image as being less monarchic in comparison to the other families, as well as the "urban" character of his rule. ${ }^{37}$ Second, he tightened relations with Cyzicus. Lastly, it cannot be ruled out that he opened the path to establishing friendly relations with Miletus, which was regarded as a metropolis by Cyzicus. ${ }^{38}$

The first evidence of the use of new topics in the Attalids' propaganda, this time of a religious-mythological nature, comes from the 220s. Attalus I founded an impressive building complex at Delphi, which occupied a special place in Apollo's sanctuary. The entire architectural layout included a terrace on which a number of statues and a stoa were placed. This was the only building which interrupted the temenos wall. It was situated directly next to the tomb of the hero Pyrrhos-Neoptolemos, son of Achilles and father of Pergamos, the eponymous hero of Pergamum and one of the Attalids' ancestors. This was probably the first manifestation of the Attalids' syngeneia.$^{39}$ The mythological themes were subsequently developed. In fact, the Attalids had to build a cohesive genealogy which would have allowed them to compete with the other Hellenistic monarchies in the field of religious policy. They propagated the idea of their descent from Zeus through Dionysus Cathegemon and Heracles, the character of the Arcadian demi-god, Telephus, who was considered the legendary predecessor of the dynasty, having become the liaison. ${ }^{40}$ It was also through the character of Heracles that they built the link connecting them with Alexander the Great. ${ }^{41}$ The role of Attalus was significant in this respect. The first indisputable evidence of the Attalids using Telephus and the Greek world's acceptance of this genealogy is the inscription engraved on Telephus' statue for the temple in Aegina in $209 .{ }^{42}$ This was yet another convenient tool for diplomacy in the relationships with the Greeks.

36 Plb. 22.20.1.

37 Koehn 2007, 62.

38 Anyway, the choice of Apollonis as Attalus' wife subsequently influenced the relationships with Miletus. When Eumenes II was honoured by the Ionian League and was supposed to decide on the place of receiving the award, as a matter of fact, he chose Miletus, cf. Seibert 1967, 61; Bringmann - von Steuben 1995, 349-353, no. 285; Kotsidu 2000, 296-297, no. 200.

${ }^{39}$ Paus. 10.2.6; cf. Strab. 9.421. As regards Attalus' stoa, see Schalles 1985, 104-126; Hintzen-Bohlen 1992, 122-127; Bernhard 1993, 136-144; Scheer 2003, 222.

${ }^{40}$ According to myths, Telephus was the son of Heracles and an Arcadian princess who, banished by her father, gave birth to her son in Mysia. In this way, the Attalids gained a purely Greek ancestor, and one who descended through Heracles from Zeus, the king of the gods himself.

${ }^{41}$ An additional link to Alexander the Great was Pergamos, chosen by the Attalids as their legendary founder. Pergamos was supposedly the king of the Epirote Molossians. Invited by Telephus' grandson, he came to Mysia. There, he assumed power and changed the name of the capital city to Pergamum. In this way, the Attalids were supposed to be related to the Epirote royal family, i.e. for instance Olympias, Alexander's mother. For the Attalid mythology and other possibilities which Telephus and Pergamos offered (e.g. including the Attalids in the oldest Hellenic tradition through references to Homer's epic stories and the Trojan War), see Scheer 1993, 71-73, 127-128; 2003, 221-226; Kosmetatou 1995, 138-144; 2003, 167-168; Gruen 2000, 22-27. For Dionysus Cathegemon, see Michels 2011, 125-139.

${ }^{42}$ Scheer 2003, 223. Delos played an important role in the Attalids' religious-mythological propaganda. Attalus founded on Delos a cleverly designed monument, the so-called "Theuthrania offering." The monument consisted of a group of five or six statues. The statues of Eumenes I and Attalus I were accompanied by the images of local Mysian heroes and, probably, of Philetaerus: $I G$ XI 4.1107; 1108; 1206-1208; Robert 1973; Schalles 1985, 127-135; Bringmann - von Steuben 1995, 218-221, no. 172; Scheer 2003, 221-222. 
Undoubtedly, the attractiveness of the king of Pergamum in the Greeks' eyes was best enhanced by his military successes. In the 230 s, the wars that he waged were defensive in nature. It was only in the years 230-223 that his actions assumed a more military character, exceeding the borderlines of the state that he had inherited from Eumenes $\mathrm{I}^{43}$ Polybius (4.48.7) overestimated the king's successes when writing that he had captured the whole country "on this side of the Taurus mountains." But indeed, Pergamum's ruler wielded influence in a large part of the Seleucids' territory, most of all, in Lydia and Hellespontic Phrygia. ${ }^{44}$ Importantly, the military actions must have been supported by diplomatic activity. As a matter of fact, after his success, Attalus faced the problem of handling the relationships with the local cities. We can conclude that the king of Pergamum applied a very flexible approach and, depending upon the region, the importance of the city and his own abilities, employed different solutions to the problem in question. ${ }^{45} \mathrm{As}$ far as can be concluded from Polybius' account concerning Attalus' expedition in 218, but containing information useful for the reconstruction of the previous relationships, the king imposed more direct control over the cities of Aeolis and Mysia. ${ }^{46} \mathrm{His}$ interference in the independence of Teos in southern Ionia was even stronger. ${ }^{47}$ What becomes very evident in the sources is the permanence of his alliances with the cities of Troad. Ilium, Lampsacus and Alexandria Troas also in fact remained loyal during the Seleucid reconquest of these territories led by Achaeus from 223 onwards. ${ }^{48}$ Undoubtedly, the strong connection between these cities and Pergamum needs to be regarded as Attalus' success - especially considering the fact that there are no sources to indicate the first two Attalids' direct involvement in Troad. ${ }^{49}$ From the point of view of the cities of Troas, the purpose of the treaties drawn up with Attalus was to maintain autonomy not only within the area of the internal policy, but also, at least to some extent, in the field of foreign af-

43 Allen 1983, 38-39.

${ }^{44}$ Given the scarcity of sources, a precise description of Attalus' conquest is difficult. Perhaps he temporarily controlled Pisidia (Kosmetatou 1997, 23). Certainly, he did not reach for Caria. In 227 Antigonus Doson organised an expedition to this land (I.Labraunda, no. 7; Plb. 20.5.11; Pompeius Trogus, Prol. 28). The king of Macedonia might have been asked for help in the fight with Attalus by the local cities or Olympichus, the Seleucid governor of Caria, cf. Bengtson 1971, 22-33; Will 1979-1982, I: 366-371; Walbank 1979, III: 70-71; Le Bohec 1993, 333-346.

45 Detailed analysis: Allen 1983, 39-58. McShane (1964, 58-91) put forward a daring hypothesis - albeit a pointless one, unsupported by any source materials - according to which Attalus reputedly created a kind of symmachy, following the example of the Hellenic League established by Antigonus Doson.

46 According to Polybius, Attalus imposed his authority by force of arms, on the same agreements as formerly. As indicated by Attalus' later (of 205) letter to the citizens of Magnesia on the Meander (OGIS $282=$ Welles 1934, no. 34), the cities enjoyed their independence as far as internal matters are concerned. However, the king controlled their activity in the outside arena, cf. Allen 1983, 45.

47 Allen 1983, 47-56; Ma 2002, 58, note 25.

48 This is indicated by Polybius' account (5.78.1-5) referring to Attalus' expedition in 218. Contra Meloni 1949, 536, note 2; 1950, 175, note 2; Schmitt 1964, 165. They both, however, over-interpret Polybius' account, cf. Ma 2002, 56, note 13.

49 We do not know the exact location of the city of Philetaereia, established by Eumenes I. It was supposed to be situated at the foot of Mount Ida, which is situated in the borderland between Mysia and Troas. According to Magie (1950, 734), it was on the eastern side of the Ida range. Allen (1983, 23, in his opinion, the founder was Philetaerus) and Stauber (1996, 11-14) give the location as the northern coast of the bay of Adramyttium in the south-east of the Troas, cf. Cohen 1995, 171-172; Kosmetatou 2001, 110-117. 
fairs. ${ }^{50}$ The cities of Troas, which, like most of the other ones in western Asia Minor, had hitherto been dependent on the Seleucids, as a result of the Third Syrian War as well as the "War of Brothers" gained the chance to become independent. In a situation in which Attalus I became the Seleucids' main opponent, he proved to be their natural ally. It is likely that Attalus was connected by still looser bonds of friendship with Smyrna, which remained a free city. ${ }^{51}$

In 223 the Seleucids' counteroffensive took place. Initially it was led by Seleucus III, and, after his sudden death, by Achaeus, who represented the power of the new king, Antiochus III, as a governor of cis-Tauric Asia Minor. Since the acceptance of the diadem in 220, Achaeus had been taking actions on his own. Consequently, Attalus I had lost almost all of the conquered territories. Taking advantage of Achaeus' involvement in Pisidia and Pamphylia, in 218 Attalus organised a successful expedition, which resulted in his regaining part of the territories that he had lost a few years before. Achaeus' reaction was not as effective as in the years 223-222.52

In 220 Byzantium strove to gain Attalus' and Achaeus' support in the war which it waged with Rhodes. Yet this does not prove that the agreement between Attalus and Achaeus took place at this time. ${ }^{53}$ A careful analysis of the text by Polybius does not confirm such a suggestion. ${ }^{54}$ However, the episode in question casts some light on the king of Pergamum's attitude towards the Rhodians. According to Polybius, the conflict resulted from Byzantium raising the customs tax levied on the ships which passed through the Hellespont. Supposedly, they were forced to take this step by the necessity to pay a tribute to the Galatian Kingdom of Tylis. ${ }^{55}$ It is possible, however, that the reasons were deeper, and there was in fact a trade war in which Byzantium was trying to increase its share of the profits from trade with Black Sea cities. Rhodes, thanks to its strategic position, played a key role in the transit trade in the eastern waters of the Mediterranean Sea, and gradually built its expansive trade contacts. Additionally, it tried to expand its dominions on the mainland and its influence on the Aegean Islands. ${ }^{56}$ The Rhodians also gained the support of Pergamum's enemy, Prusias II, king of Bithynia, during this war. ${ }^{57}$ The support given by the Rhodians to the Seleucids and the Antigonids during the Second Syrian War was also definitely not to the Attalids' liking. ${ }^{58}$ It is also telling that Attalus was not among the kings and states which supported the Rhodians after the

50 Kosmetatou 2001, 118.

51 Plb. 5.77.6. Smyrna also remained loyal to Attalus during the attack of Seleucus III and Achaeus.

52 Plb. 4.48; 5.77-78; cf. Hansen 1971, 40-43; Ma 2002, 54-59; Evans 2012, 20-21; Chrubasik 2016, 83-84. Around 223-222 Ptolemy III sent Attalus some support (P. Haun. 6, frg. 1; cf. Huss 1977; BeyerRotthoff 1993, 72-73). The expedition was an episode in terms of the Ptolemies' military involvement in the war in Asia Minor. It proved, however, the political support that Attalus was provided with.

53 Establishing such a peace or an agreement was assumed, among many others, by Schmitt 1964, 262; Hansen 1971, 40; Allen 1983, 37; Heinen 1984, 431.

54 Detailed analysis by Ager 2012. The possibility of establishing such an agreement was also rejected by Meloni 1949, 552; McShane 1964, 65, note 23; Ma 2002, 58, note 22.

55 Plb. 4.46.1-48.2.

${ }^{56}$ Cf. Fraser - Bean 1954, 138-158; Berthold 1984, 81-101; Reger 1994, 41-43, 62-68; Gabrielsen 1997, 56-57; Reger 1999, 76-86; Badoud 2014, 115-124.

57 Plb. 4.45.9-47.7; 49.1-5.

58 Lind. Temp. Chron. 37; Polyaen. 5.18. 
disastrous earthquake in 227. ${ }^{59}$ Consequently, Attalus had plenty of reasons to consider assisting the Byzantinians. In the end, however, he did not join the war, probably as he was too exhausted from the war with Achaeus. ${ }^{60}$

A new opening in Asia Minor occurred in 216 when Attalus made an agreement with Antiochus III. It was probably not a formal treaty, but an obligation to conduct a temporary military cooperation. ${ }^{61}$ At the time Antiochus III was preparing for a military encounter with Achaeus, whom he considered a usurper who, by assuming a royal title, had become a mutual enemy of Antiochus and Attalus. We can only speculate about specific territorial concessions. ${ }^{62}$ It seems, however, that Attalus kept only the territories which had been previously taken away from him by Achaeus. Establishing an agreement, however, meant Antiochus' recognition of the sovereignty of the kingdom of Pergamum.

The agreement withAntiochus III normalised for several years the relationships between the two states, allowing Attalus to focus his attention on other territories - Greece and the Aegean Sea. ${ }^{63}$ Attalus' significant success was establishing closer relationships with the Greek cities in Asia Minor. This reinforced Pergamum's position in its relations with the local opponents. A certain indicator of not only the propaganda skills, but also the diplomatic talents displayed by Attalus is Polybius' most positive assessment. ${ }^{64}$

ABBREVIATIONS

I.Didyma - A. Rehm, Didyma II: Die Inschriften, Berlin 1958.

$I G$ - Inscriptiones Graecae.

I.Ilium - P. Frisch, Die Inschriften von Ilion, Bonn 1978.

I.Labraunda - J. Crampa, Labraunda: Swedish Excavations and Researches, vol. III,1: The Greek Inscriptions, Lund 1969.

I.Milet - C. Fredrich, Das Rathaus von Milet, Berlin 1908.

I.Orop. - V. Petrakos, Les inscriptions d'Oropos, Athens 1997 [in Greek].

I.Smyrna - G. Petzl, Die Inschriften von Smyrna, Bonn 1982-1990.

${ }^{59} \mathrm{Plb}$. 5.88.1 - 90.4. Polybius gives very specific information about the assistance given to the Rhodians. He must have used an official Rhodian document, either directly or through the work of one of the local historians, cf. Kobes 1993, 6-7. It is impossible that he accidentally overlooked Attalus I.

${ }^{60} \mathrm{Plb}$. 4.48.2.

${ }^{61} \mathrm{Plb}$. 5.107.4. Polybius uses the term koinopragia (otherwise unknown) to define this agreement. It is very likely that its extension was a subsequent agreement between the two rulers, which is mentioned by Polybius (21.17.6) in his account concerning the negotiations between Rome and Antiochus III in 189. The Greek historian mentions in this context the synthekai between Antiochus and Attalus, according to which the former was supposed to return to the then king of Pergamum, Eumenes II 400 talents of debt and corn. A similar term is used by Appian (Syr. 38). Unfortunately, the term synthekai is one that we know very little about. It is possible that it was a kind of agreement or treaty, the conditions of which were more specifically defined. Cf. Schmitt 1964, 264; Walbank 1979, III: 110; Allen 1983, 58-65; cf. Chrubasik 2013, 96-97.

${ }^{62}$ Mysia and Hellespontine Phrygia according to Schmitt (1964, 264-267), and Mysia and Aeolis according to Allen $(1983,58-65)$. Ma $(2002,60)$ believes that almost the whole of Mysia went to Antiochus III, and Attalus was left only with those territories which he managed to save during the war against Achaeus.

${ }_{63}^{63}$ As early as 210, the king of Pergamum joined the war between Rome and Macedonia.

${ }^{64}$ Plb. 18.41.1-10. 
BIBLIOGRAPHY

Ager, S.L. (2012), The Alleged Rapprochement between Achaios and Attalos I in 220 BCE, Historia 61: 421-429.

Allen, R.E. (1971), Attalos I and Aigina, BSA 66: 1-12.

Allen, R.E. (1983), The Attalid Kingdom: A Constitutional History, Oxford.

Atkinson, K.M.T. (1968), The Seleucids and the Greek Cities of Western Asia Minor, Antichton 2: 32-57.

Badoud, N. (2014), Rhodes et les Cyclades à l'époque hellénistique, in: G. Bonin, E. Le Quéré (eds.), Pouvoir, îles et mer. Formes et modalités de l'hégémonie dans les Cyclades antiques (VII ${ }^{e}$ s. a.C.$I I I^{e}$ s. p.C.), Bordeaux: 115-129.

Bengtson, H. (1971), Die Inschrift von Labranda und Politik Antigonos Doson (Sitzungsberichte der Bayerischen Akademie der Wissenschaften. Philosophisch-historische Klasse 3), München.

Bernhard, M.L. (1993), Sztuka hellenistyczna, Warszawa.

Berthold, R.M. (1984), Rhodes in the Hellenistic Age, Ithaca-London.

Beyer-Rotthoff, B. (1993), Untersuchungen zur Aussenpolitik Ptolemaios'III, Bonn.

Bringmann, K., Steuben, H. von (eds.) (1995), Schenkungen hellenistischer Herrscher an griechische Städte und Heiligtümer, Teil I: Zeugnisse und Kommentare, Berlin.

Buraselis, K. (2012), Appended Festivals, in: J. Rasmus Brandt, J.W. Iddeng (eds.), Greek and Roman Festivals: Content, Meaning, and Practice, Oxford: 247-266.

Capdetrey, L. (2007), Le pouvoir séleucide. Territoire, administration, finances d'un royaume hellénistique (312-129 avant J.-C.), Rennes.

Chrubasik, B. (2013), The Attalids and the Seleukid Kings, 281-175 BC, in: P. Thonemann (ed.), Attalid Asia Minor: Money, International Relations, and the State, Oxford: 49-82.

Chrubasik, B. (2016), Kings and Usurpers in the Seleukid Empire: The Men who Would be King, Oxford.

Cohen, G.M. (1995), Hellenistic Settlements in Europe, the Islands and Asia Minor, Berkeley-Los Angeles.

Dmitriev, S. (2011), The Greek Slogan of Freedom and Early Roman Politics in Greece, Oxford.

Evans, R. (2012), History of Pergamum: Beyond Hellenistic Kingship, London.

Fraser, P.M., Bean, G.E. (1954), The Rhodian Peraea and Islands, Oxford.

Gabrielsen, V. (1997), The Naval Aristocracy of Hellenistic Rhodes, Aarhus.

Gauthier, P. (2003), De nouveaux honneurs cultuels pour Philétairos de Pergame: À propos de deux inscriptions récemment publiées', Studi Ellenistici 15: 9-23.

Grabowski, T. (2011), Achaeus, the Ptolemies and the Fourth Syrian War, Electrum 18: 115-124.

Grabowski, T. (2016), The Aegean Islands in The Politics of the Attalid Dynasty, Electrum 23: 77-99.

Gruen, E.S. (2000), Culture as Policy: The Attalids of Pergamon, in: N.T. de Grummond, B.S. Ridgway (eds.), From Pergamon to Sperlonga: Sculpture and Context, Berkeley-Los Angeles-London: $17-31$.

Hannestad, L. (1994), Greeks and Celts: The Creation of a Myth, in: P. Bilde et al. (eds.), Centre and Periphery in the Hellenistic World, Aarhus: 15-38.

Hansen, E.V. (1971), The Attalids of Pergamon, $2^{\text {nd }}$ ed., Ithaca.

Heinen, H. (1984), The Syrian Egyptian Wars and the New Kingdoms of Asia Minor, $C A H^{2}$, VII.1: 412-445.

Heuss, A. (1937), Stadt und Herrscher des Hellenismus in ihren staats- und völkerrechtlichen Beziehungen, Leipzig.

Hintzen-Bohlen, B. (1992), Herrscherrepräsentation im Hellenismus: Untersuchungen zu Weihgeschenken, Stiftungen und Ehrenmonumenten in den mutterländischen Heiligtümern Delphi, Olympia, Delos und Dodona, Köln.

Hölbl, G. (2001), A History of the Ptolemaic Empire, London. 
Holleaux, M. (1938), Un nouveau document relatif aux premiers Attalides, in: M. Holleaux, Études d'Épigraphie et d'Histoire Grecques, vol. II, Paris: 9-16.

Huss, W. (1977), Eine ptolemäische Expedition nach Kleinasien, AncSoc 8: 187-193.

Huss, W. (2001), Ägypten in hellenistischer Zeit 332-30 v.Chr., München.

Kobes, J. (1993), Rhodos und das Erdbeben von 227 v.Chr., MBAH 12: 1-26.

Koehn C. (2007), Krieg - Diplomatie - Ideologie. Zur Außenpolitik hellenistischer Mittelstaaten, Stuttgart.

Kosmetatou, E. (1995), The Legend of the Hero Pergamus, AncSoc 26: 133-144.

Kosmetatou, E. (1997), Pisidia and the Hellenistic Kings from 323 to 133 BC, AncSoc 28: 5-37.

Kosmetatou, E. (2001), Ilion, the Troad, and the Attalids, AncSoc 31: 107-132.

Kosmetatou, E. (2003), The Attalids of Pergamon, in: A. Erskine (ed.), A Companion to the Hellenistic World, Oxford: 105-120.

Kotsidu, H. (2000), TIMH KAI DOXA. Ehrungen für hellenistische Herrscher im griechischen Mutterland und in Kleinasien unter besonderer Berücksichtigung der archäologischen Denkmäler, Berlin.

Launey, M. (1949-1950), Recherches sur les armées hellénistiques, vol. I (1949); II (1950), Paris.

Le Bohec, S. (1993), Antigone Dôsôn, roi de Macedoine, Nancy.

Ma, J. (2002), Antiochos III and the Cities of Western Asia Minor, Oxford.

Magie, D. (1950), Roman Rule in Asia Minor to the End of the Third Century after Christ, 2 vols., Princeton.

Manganaro, G. (2000), Cyme e il dinasta Philetairos, Chiron 30: 403-414.

Marszal, J.R. (2000), Ubiquitous Barbarians: Representations of the Gauls at Pergamon and Elsewhere, in: N.T. de Grummond, B.S. Ridgway (eds.), From Pergamon to Sperlonga: Sculpture and Context, Berkeley-Los Angeles-London: 191-234.

McShane, R.B (1964), The Foreign Policy of the Attalids, Urbana.

Meloni, P. (1949), L'usurpazione di Acheo sotto Antioco III re di Siria, RAL (serie 8) 4: 535-553.

Meloni, P. (1950), L'usurpazione di Acheo sotto Antioco III re di Siria, RAL (serie 8) 5: 161-183.

Michels, C. (2011), Dionysos Kathegemon und der attalidische Herrscherkult. Überlegungen zur Herrschaftsrepräsentation der Könige von Pergamon, in: L.-M. Günther, S. Plischke (eds.), Studien zum vorhellenistischen und hellenistischen Herrscherkult: Verdichtung und Erweiterung von Traditionsgeflechten, Berlin: 114-140.

Mitchell, S. (2003), The Galatians: Representation and Reality, in: A. Erskine (ed.), A Companion to the Hellenistic World, Oxford: 280-293.

Muccioli, F. (2013), Gli epiteti ufficiali dei re ellenistici, Stuttgart.

Nachtergael, G. (1975), Les Galates en Grèce et les Sôtéria de Delphes. Recherches d'histoire et d'épigraphie hellénistiques, Brussels.

Newell, E.T. (1936), The Pergamene Mint under Philetaerus, New York.

Pirson, E. (2004), Elaia, der maritime Satellit Pergamons, Istanbuler Mitteilungen 54: 197-213.

Pirson, E. (2014), Elaia, der (maritime) Satellit Pergamons, in: S. Ladstätter, F. Pirson, T. Schmidts (eds.), Harbors and Harbor Cities in the Eastern Mediterranean from Antiquity to the Byzantine Period: Recent Discoveries and Current Approaches, BYZAS 19: 339-356.

Reger, G. (1994), The Political History of the Kyklades 260-200 B.C., Historia 43: 32-69.

Reger, G. (1999), The Relations between Rhodes and Caria from 246 to 167 BC, in: V. Gabrielsen et al. (eds.), Hellenistic Rhodes: Politics, Culture, and Society, Aarhus: 76-97.

Robert, L. (1937), Études anatoliennes. Recherches sur les inscriptions grecques de l'Asie Mineure, Paris.

Robert, L. (1973), Sur les inscriptions de Délos, BCH Suppl. 1: 435-489.

Schalles, H.J. (1985), Untersuchungen zur Kulturpolitik der pergamenischen Herrscher im 3. Jahrhundert v.Chr., Tübingen.

Scheer, T.S. (1993), Mythische Vorväter. Zur Bedeutung griechischer Heroenmythen im Selbstverständnis kleinasiatischer Städte, München.

Scheer, T.S. (2003), The Past in a Hellenistic Present: Myth and Local Tradition, in: A. Erskine (ed.), A Companion to the Hellenistic World, Oxford: 216-231. 
Schmitt, H.H. (1964), Untersuchungen zur Geschichte Antiochos'des Grossen und seiner Zeit, Wiesbaden.

Seibert, J. (1967), Historische Beiträge zu den dynastischen Verbindungen, Wiesbaden.

Stauber J. (1996), Die Bucht von Adramytteion, vol. 1: Topographie (Lokalisierung antiker Orte, Fundstellen von Altertümern), Bonn.

Strobel, K. (1994), Keltensieg und Galatersieger. Die Funktionalisierung eines historischen Phänomens als politischer Mythos der hellenistischen Welt, in: E. Schwertheim (ed.), Forschungen in Galatien, Bonn: 67-96.

Strobel, K. (1996), Die Galater. Geschichte und Eigenart der keltischen Staatenbildung auf dem Boden des hellenistischen Kleinasien, vol. 1, Berlin.

Virgilio, B. (1993), Gli Attalidi di Pergamo. Fama, Eredità e Memoria, Pisa.

Walbank, F.W. (1967-1979), A Historical Commentary on Polybius, vol. I (1970), II (1967), III (1979), Oxford.

Welles, C.B. (1934), Royal Correspondence in the Hellenistic Period: Study in Greek Epigraphy, New Haven.

Westermark, U. (1961), Das Bildnis von Philetairos von Pergamon, Stockholm.

Will, É. (1979-1982), Histoire politique du monde hellénistique (323-30 av. J.-C.), vol. I-II, Nancy. 